\title{
Agrometeorological conditions associated with phenological responses of tucumã-do-pará (Astrocaryum vulgare Mart.)
}

\author{
Condições agrometeorológicas associadas às respostas fenológicas de \\ tucumã-do-pará (Astrocaryum vulgare Mart.)
}

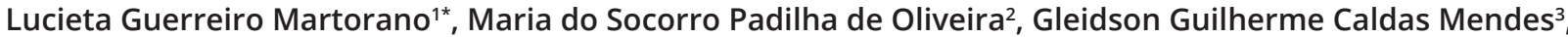 José Reinaldo da Silva Cabral de Moraes ${ }^{4}$, Daniel Pereira Pinheiro ${ }^{5}$, Afonso Henrique Moraes Oliveira ${ }^{6}$}

\author{
1Embrapa Amazônia Oriental/NAPT, Santarém, PA, Brazil \\ ${ }^{2}$ Embrapa Amazônia Oriental, Belém, PA, Brasil \\ ${ }^{3}$ Universidade Federal de Viçosa/UFV, Viçosa, MG, Brasil \\ ${ }^{4}$ Universidade Estadual Paulista/Unesp, Escola de Ciências Agrárias e Veterinárias, Jaboticabal, Brasil \\ EUniversidade Federal Rural da Amazônia/UFRA, Capanema, Pará, Brasil \\ ${ }^{6}$ Instituto Nacional de Pesquisas Espaciais/INPE, São José dos Campos, SP, Brasil \\ *Corresponding author: lucietamartorano@embrapa.br; martorano.lucietta@gmail.com \\ Received in December 19, 2017 and approved in April 4, 2018
}

\begin{abstract}
Palms are among the class of hyperdominant species in the Amazon region, and for the tucumã palm (Astrocaryum vulgare Mart.) demand of climatic and phenological information in order to support strategic planning and sustainable management of this palm species native to the Amazon basin. The objective of this work was to evaluate agrometeorological conditions associated to phenological responses of tucumã as a species that has high economic potential for fruit pulp production. Meteorological data were collected during the period in which data were also collected for the phenology of the germplasm bank. Sensors were installed to monitor temperature and air relative humidity to where they are observed as phenophases. Analyses were conducted to identify the responses of the tucumã stems in function of agrometeorological conditions of the study area. Precipitation, thermal amplitude, and insolation showed positive correlations principally with respect to the percent of stems with bracts, inflorescences, or with fertilized inflorescences. In the fruiting phenological phase precipitation and air relative humidity influenced the percentage of stems with fruit clusters that were immature and also ones with mature clusters. High maximum temperatures compromise the expression of the percentage of stems with green fruit clusters. The tucumã stems were photosynthesizing and carrying out metabolic processes at a very high rate during the study period based on the high Normalized Difference Vegetation Index which was superior to 0.41 during the three years of this study. The tucumã phenological phases, demonstrating a strong positive association with insolation, maximum temperature and thermal amplitude.
\end{abstract}

Index terms: Palmaceae; phenology; climate; germplasm bank.

\section{RESUMO}

As palmeiras estão entre as espécies hiperdominantes na Amazônia e o tucumã (Astrocaryum vulgare Mart.) demanda de informações climáticas e fenológicas para subsidiar o planejamento estratégico e o manejo sustentável dessa palmacea nativa da região. O objetivo neste trabalho foi avaliar as condições agrometeorológicas associadas às respostas fenológicas do tucumã por ser uma espécie que apresenta alto potencial econômico na produção de polpa dos frutos. Foram levantados dados meteorológicos correspondentes ao período em que foram realizadas as coletas de dados de fenologia no Banco de Germoplasma. Também, foram instalados sensores para monitorar a temperatura e a umidade relativa do ar onde eram observadas as fenofases. Foram realizadas análises para identificar respostas dos tucumanzeiros em função das condições agrometeorológicas na área de estudo. A precipitação pluvial, amplitude térmica e insolação apresentaram correlações positivas principalmente quanto aos percentuais de indivíduos com brácteas, de indivíduos com inflorescências e de indivíduos com inflorescências fecundadas. Nas fenofases de frutificação a precipitação pluvial e a umidade relativa do ar influenciaram nos percentuais de indivíduos com cachos de frutos imaturos e de indivíduos com cachos de frutos maduros. Temperaturas máximas elevadas comprometem a expressão da porcentagem de indivíduos com cachos verdes do tucumã. Os tucumanzeiros estavam em plena capacidade vegetativa durante as avaliações a campo, pois o NDVI manteve-se, dominantemente superior a 0,41 nos três anos analisados. As fenofases do tucumã demonstrando forte associação positiva com insolação, temperatura máxima e amplitude térmica.

Termos para indexação: Palmacea; fenologia; clima; banco de germoplasma.

\section{INTRODUCTION}

Anthropogenic pressure (Gilman et al., 2010) in areas of native vegetation with high biodiversity in the Amazon region, due to typical climatic conditions of humid tropical forest, is threatening these areas with species loss (Lapola et al., 2008; Lapola; Oyama; Nobre, 
2009; Poorter et al., 2015). These areas are also important because they provide essential ecosystem services (Agarwala et al., 2014) such as provision of diverse food sources, regulation of climate, water, and nutrient cycles, and support for human cultural activities.

According to Steege et al. (2013), in lowland areas of the Amazon there are approximately 16,000 species of trees with just 227 of these being hyperdominant (1.4\% of the total). These species are dominant in two large geographic areas of the Amazon basin and include species from the Arecaceae, Myristicaceae and Lecythidaceae families. This reinforces the idea that the biogeochemical cycles of the largest tropical forest in the world are supported by the growth of just a small portion of its floristic diversity.

In this context, palms are part of the species that make up this hyperdominant group, and evaluation of areas of their natural occurrence and their environmental characteristics, along with germplasm bank analyses are fundamental to the identification of possible responses of these species to climatic variables.

It is known that Amazonian biodiversity is a product of a combination of various factors such as the size of the forested area, high levels of production, spatial and temporal variability in edaphic and climatic characteristics and ecosystem stability, factors that are responsible for transformations of floristic patterns in this region that is considered the world's richest in terms of species (Malhado et al., 2013).

Another important factor of this ecosystem is that in areas that have, over time, suffered successive fires, there is a predominance of palms, and among them there is an abundance of tucumã (Astrocaryum vulgare Mart.), principally in the west of the State of Pará. This palm has great economic importance because its fruit can be consumed in natura, and also because the pulp processed from the fruit is used in juices, cakes, jellies, ice creams, liquors and other food items, as well as in the cosmetic and pharmaceutical industries (Oliveira et al., 2015). This being the case, in the current study the following questions were elaborated with respect to tucumã:

Is there a suite of agrometeorological conditions that could aid in the identification of factors that are able to explain the occurrence of phenological phases such as flowering and fruiting which could, in turn, help to strengthen germplasm bank studies (BAG) conducted at Embrapa Eastern Amazon? Is it possible to identify seasonal patterns that present environmental conditions associated with expression of phenological phases of tucumã in the Amazon?
Biondi, Leal and Batista (2007) related that knowledge of the phenological phases of plants can serve as a base for the collection of fertile genetic material as well as for studies of species reproduction with the goal of conservation of biomes and recuperation of degraded areas. It is important to emphasize that the study of plant phenology is focused on recurrent biological events related to plant development stages that are influenced by biotic and abiotic factors, including the emergence of leaves, florescence, and fruitification (Morisette et al., 2009), that are sensitive to changes in climate and in the natural environment in general (Conga et al., 2012).

In this context, this study had as objective the evaluation of agrometeorological variables capable of explaining the responses of the different phenological phases of tucumã, including flowering and fruiting, in areas that have a germplasm bank (BAG-Tucumã) that is part of a research area at Embrapa Eastern Amazon in Belém, the capital of the State of Pará.

\section{MATERIAL AND METHODS}

In order to evaluate the climate conditions of the study area climate data from the National Meteorological Institute (INMET, 2017) were used. These data correspond to the historical series available for Belém $\left(01^{\circ} 27^{\prime} \mathrm{S} ; 48^{\circ}\right.$ $30^{\prime} \mathrm{W} ; 10 \mathrm{~m}$ ), from 1990 to 2017.

Temperature (Tmax, Tmin, Amp) and relative humidity sensors were installed and data were recorded using HOBO U12 data loggers in order to evaluate the agrometeorological conditions capable of explaining phenological responses of tucumã stems growing at the Embrapa Eastern Amazon germplasm bank during the month of June, 2015. The agrometeorological sensor box was installed at the base of the palm leaf sheaths with the purpose of evaluating the micro-environment wherein occur the monitored phenological responses (Figure 1).

The agrometeorological variables were correlated with phenological phases that were monitored on a monthly basis with respect to the following phases: flowering: SWB (\% of stems with bracts); SWI (\% of stems with inflorescences); SWFI (\% of stems with fertilized inflorescences); SWDI (\% of stems with dried inflorescences). The variables analyzed in the fruiting phase were SWGFC ( $\%$ of stems with green fruit clusters); SWIFC (\% of stems with immature fruit clusters); SWMFC (\% of stems with mature fruit clusters); and SWDFC (\% of stems with dry fruit clusters). Each phase was evaluated in function of temperature and air relative humidity, rainfall, and insolation, and Figure 2 shows the location of the monitored stems (182 plants in the germplasm bank). 


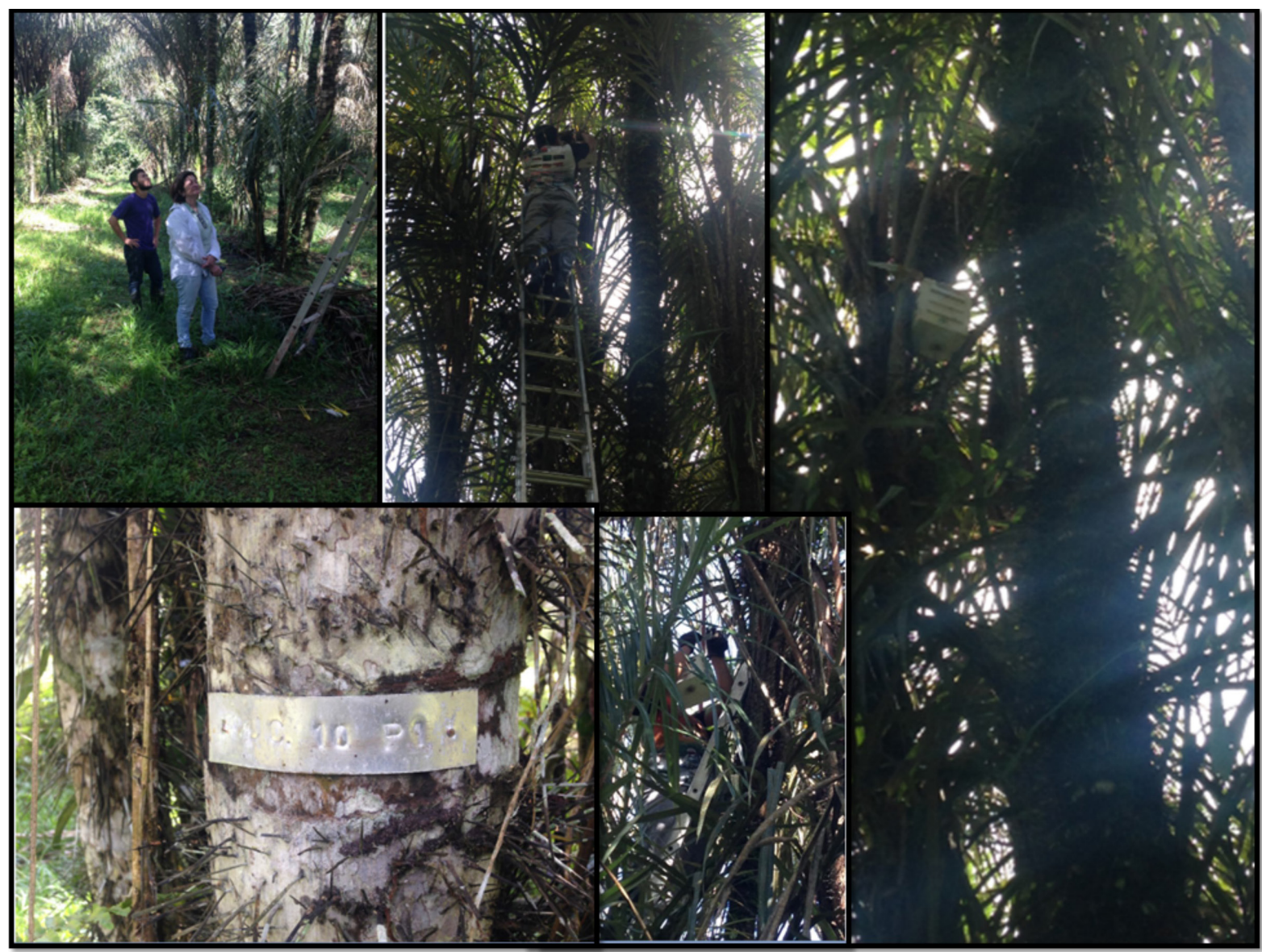

Figure 1: Images identifying the installation of the temperature and humidity sensors in order to evaluate the phenological responses associated to climatic conditions in the study area.

A Pearson correlation matrix was constructed to evaluate the degree of association between the variables, and variables that had a value for coefficients above 0.30 were selected. A principal component factorial analysis was then conducted with the goal of identifying latent variables that could be used as factors for explaining the phenological phases. In order to evaluate the adequacy of the data the factorial analysis used the KMO index (Kaiser-Meyer-Olkin Measure of Sampling Adequacy) Bartlett spherical test statistic to test the null hypothesis that the analyzed variable was not correlated (Hair-JR et al., 2009, Garson, 2011). After the factorial analysis the values of the variables were standardized and submitted to One-Way ANOVA. The Principal Components Analysis (PCA) showed the importance of the agrometeorological parameter for a specific phenological phase through the angle between the weight vector and the axis of the principal component (Nonato et al., 2007).
The data were also submitted to multivariate analysis (Sharma, 1996) in order to identify non-linear relationships in the dataset, following the suppositions described in Simeonov et al. (2002). In order to support agrometeorological evaluations satellite images from the Operational Land sensor (OLI) on board the Landsat 8 satellite were used, corresponding to the scene 223/61. Braz, Águas and Garcia (2015) relate that, in order to minimize seasonal effects, the images should be obtained on similar dates of the year so that atmospheric conditions do not interfere with the spectral response, and consequently, with the analysis of the vegetation. Images from the month of June for the years 2014 to 2016 were used to calculate the NDVI index since the sensor shows less interference from the atmosphere during this period. The NDVI values vary between (-1) and (1), and values closer to 1 indicate greater vigor of the vegetation cover, and values closer to (-1) indicate less vigorous or dense vegetation (Ponzoni; Shimabukuro, 2007). 

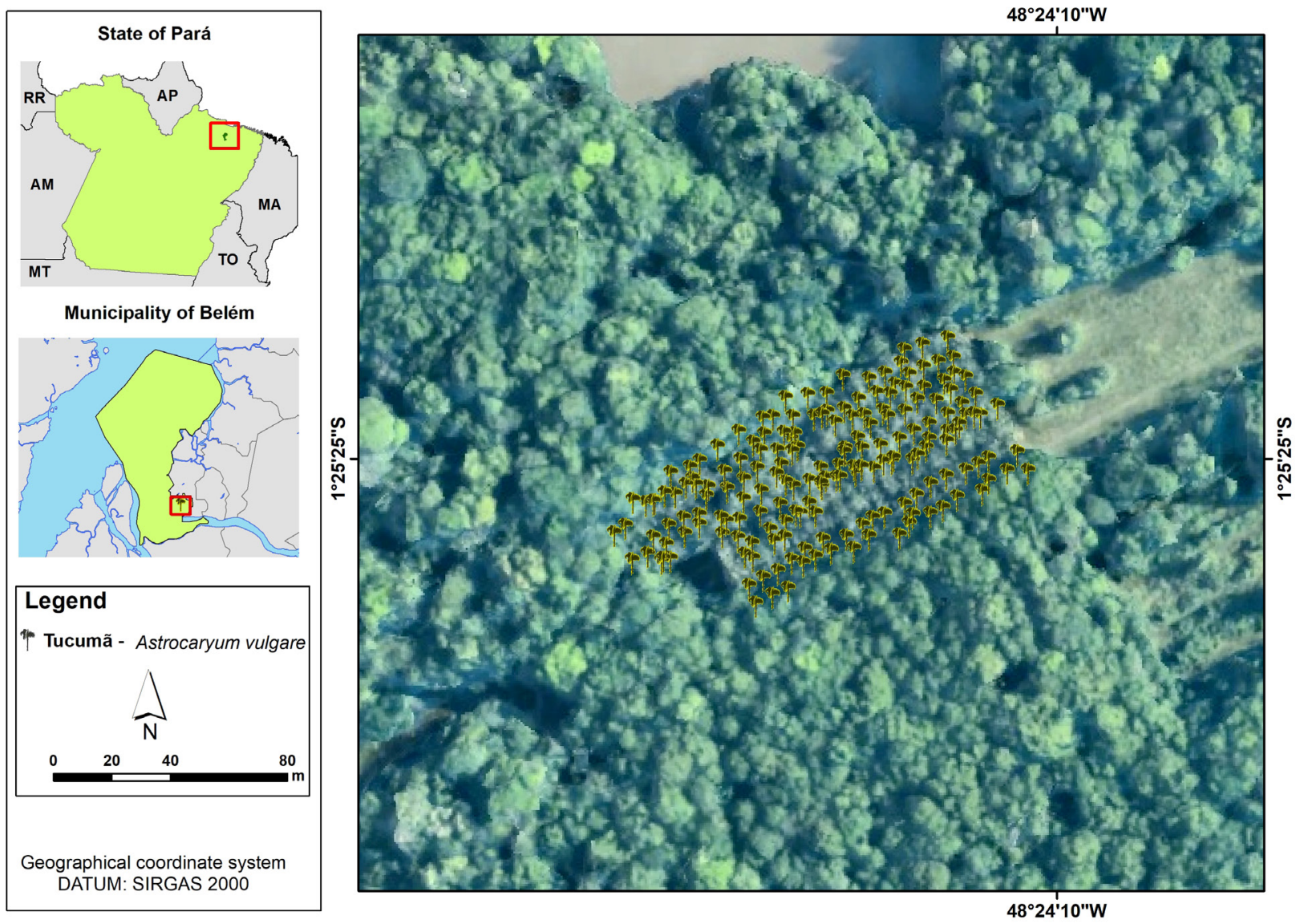

Figure 2: Monitored stems at the BAG-Tucumã at Embrapa Eastern Amazon, Belém, Pará.

O NDVI was analyzed using Equation 1:

$N D V I=\frac{(I V P-V)}{(I V P+V)}$

Where IVP represents the surface reflectance in the near infrared (between 0.75 to $0.90 \mu \mathrm{m}$ ), and $\mathrm{V}$ is the reflectance in the red band $(0.63-0.70 \mu \mathrm{m})$.

The Normalized Difference Vegetation Index (NDVI) and expressed as the ratio of the difference and the sum of the averages for reflectance in the red and near infrared canals (Rouse et al., 1973). The histograms for the images were analyzed to identify NDVI intervals that best represent the targets. The classes were reclassified and subsequently analyzed. Therefore, the NDVI was used to evaluate whether or not the tucumã stems were expressing a high rate of physiological activity and photosynthesis thus aiding in the remainder of the analyses conducted in the study area.

\section{RESULTS AND DISCUSSION}

The analysis of the flowering phenological phases (SWB, SWI, SWFI and SWDI), showed that tucumã flowered between the months of April and August, months that correspond to a reduction in rainfall in the region, with the greatest occurrence of opening of bracts in April and fertilization of inflorescences in August (Figure 1). In the fruiting phases, (SWGFC, SWIFC, SWMFC and SWDFC), the phase SWGFC exhibited the lowest concentrations between the months of April and June, influenced by the lack of fertilization of flowers due to the fact that this was the period of highest rainfall. However, the other phases expressed a strong relationship with the months of low rainfall and high temperatures in the region, conditions that begin before these phenological stages of tucumã (Figure 3 ). The high rate of loss could be attributed to not only effects of environmental variables, but also to anthropogenic activities of harvest of mature fruit clusters in the BAG-Tucumã. 


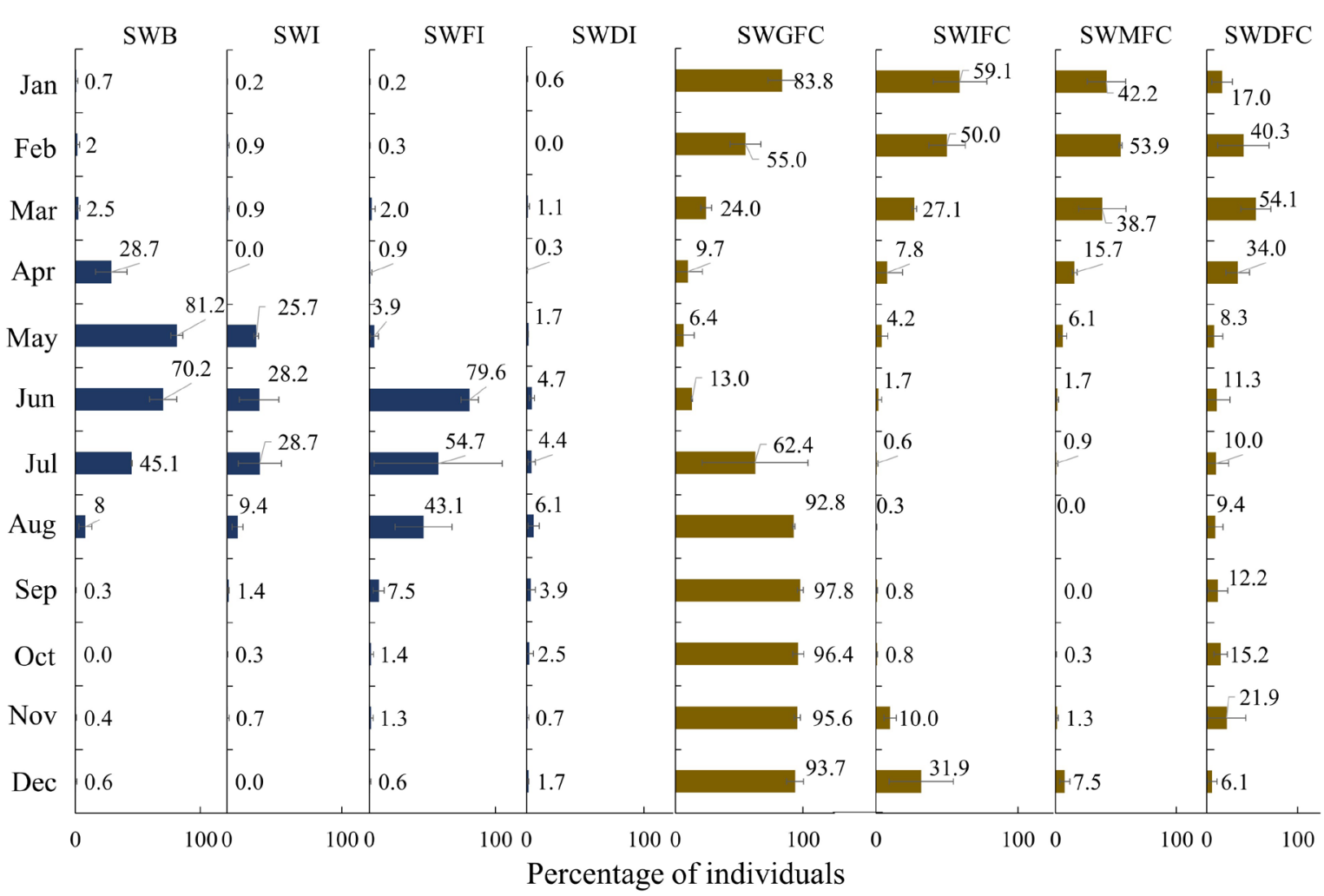

Figure 3: Phenological phases corresponding to the flowering and fruiting periods of Tucumã (A. vulgare Mart.). SWB (\% of stems with bracts); SWI (\% of stems with inflorescences); SWFI (\% of stems with fertilized inflorescences); SWDI (\% of stems with dried inflorescences); SWGFC (\% of stems with green fruit clusters); SWIFC (\%of stems with immature fruit clusters); SWMFC (\%of stems with mature fruit clusters); SWDFC (\%of stems with dry fruit clusters).

During the study period between January 2014 to January 2017, the months with the highest rainfall were between December and June, with rainfall concentrated in March and April, with $560 \mathrm{~mm}$ and $510 \mathrm{~mm}$, respectively. Between August and November there was less rainfall with September having the lowest amount with values below $100 \mathrm{~mm}$. Air relative humidity was highest in March with average values near $90 \%$, and in November humidity was below $75 \%$. These observations are in agreement with Martorano et al. (2017), who evaluated rainfall variability and indicators of soil water deficits in Belém, Pará. Figure 4 shows that between July and November there are decreases in rainfall and consequently in air relative humidity.

With respect to thermal conditions, there was much less variation in the data. The maximum temperatures (Tmax) varied between 30 to $35^{\circ} \mathrm{C}$, and the minimum temperatures (Tmin) followed the same pattern with values between 22 and $24{ }^{\circ} \mathrm{C}$.

The month with the highest thermal amplitude was November with values near $10^{\circ} \mathrm{C}$. The number of hours of insolation indicated that between January and March average insolation was about 6 hours, and between August and November this value was nearly 10 hours, with the longest day being registered in August (Figure 5a). Evaluating the daily data at the study site (Figure 5b), the highest average daily temperature occurred about 3 p.m., and the lowest temperatures occurred at sunrise around 6 a.m. With respect to air relative humidity, at noon the atmosphere was more humid than at $6 \mathrm{p} . \mathrm{m}$. Thus, these values provide a summary of the agrometeorological conditions measured at the BAGTucumã site during the study period.

The correlation analysis showed that the strongest positive correlation was for rainfall, indicating that when it rains more the responses for fruiting for the variables SWIFC, SWMFC and SWDFC are more expressive in tucumã. Furthermore, when there are fewer hours of insolation the expression of these phenological phases of fruiting is greater (Figure 6). The inverse occurred for the phenological phases for flowering wherein the emission of bracts (SWB) was positively correlated with the 
volume of rainfall and the number of hours of insolation, followed by the variables SWI, SWFI, and SWDI, indicating that during flowering these variable are highly correlated. Therefore, a reduction in the number of hours of insolation will compromise the flowering phase. The thermal amplitude was positively correlated with SWGFC, indicating that when greater amounts of energy are lost to the atmosphere, this variable will be more intensely expressed (Figure 6).
Figure 6. Correlation between agrometeorological variables and phenological phases of flowering and fruiting at the BAG - Tucumã, in Belém-PA. (Climate variables, RAI (Rainfall); Ins (Insolation); RH (Relative humidity); Amp (Thermal Amplitude); Tmin (Temperature minimum); Tmax (Temperature maximum). Phenological phases, SWB (\% of stems with bracts); SWI (\% of stems with inflorescences); SWFI ( $\%$ of stems with fertilized inflorescences); SWDI ( $\%$ of stems with

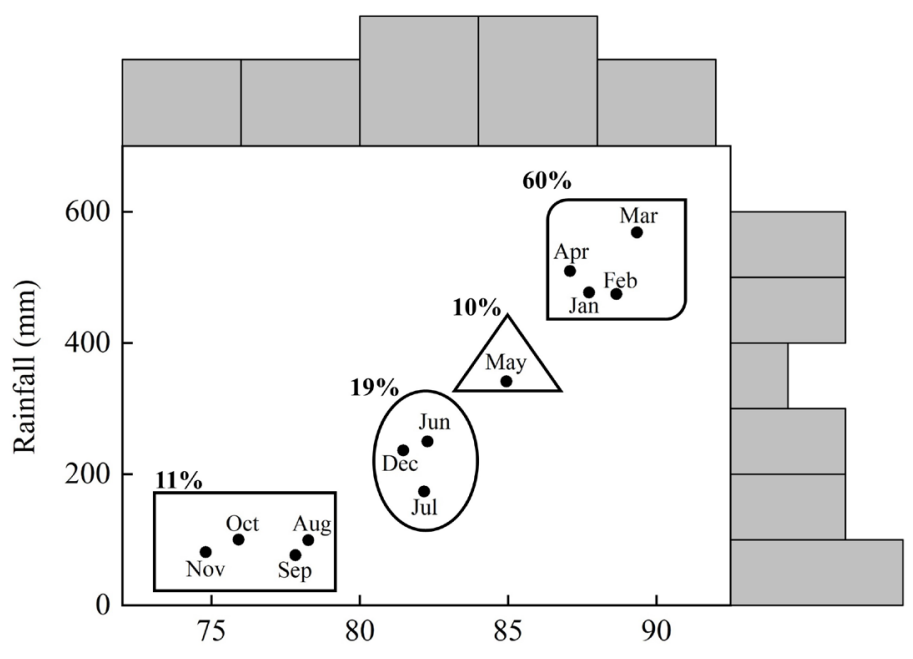

Air relative humidity $(\%)$

Figure 4: Variability in rainfall and air relative humidity between January 2014 and January 2017 in Belém-PA. representing $11 \%$ of the annual rainfall; $O$ representing $19 \%$ of the annual rainfall; $\Delta$ months representing $10 \%$ of the annual rainfall; $\square$ months representing $60 \%$ of the annual rainfall.
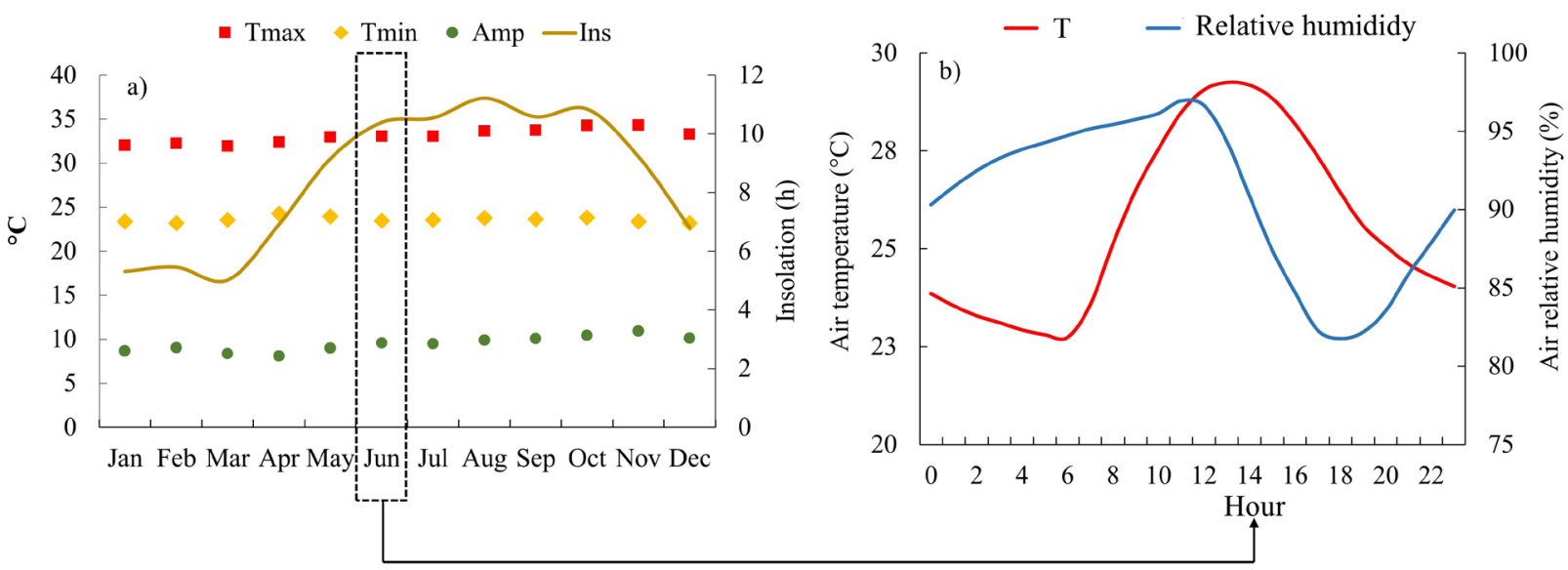

Figure 5: (a) Monthly temperature values (maximum-Tmax; minimum-Tmin and Thermal Amplitude-Amp) and insolation (Ins) between January 2014 to January 2017 in Belém-PA. (b) Daily data (temperature -T and relative humidity) on the month of July, 2016, in Belém-PA. 
dried inflorescences); SWGFC (\% of stems with green fruit clusters); SWIFC (\% of stems with immature fruit clusters); SWMFC (\% of stems with mature fruit clusters); SWDFC (\% of stems with dry fruit clusters).

It is important to emphasize that the values for insolation (h) indicate that more than $70 \%$ of the stems between May 2015 and May 2016 had bracts and fertilized inflorescences when insolation was greater than 8 hours. In 2016 there was greater exposure to solar radiation which could have contributed to a greater uniformity of plants with fertilized inflorescences at the BAG - Tucumã.

Table 1 shows the factor load for each agrometeorological variable evaluated with the phenological variables. We analyzed the weight matrix for each variable using 2 factors and verified that the absolute values of the negative weights for SWB, SWI, SWFI, and the flowering phase are associated, but they express less dependence on climatic variables than phase of fruiting. The results of the principal component analysis are shown in Figures 7 and 8. The two-dimensional plane (Figure 7) generated with the first two major components factor 1 and factor 2 account for $79.09 \%$ (50.31\% factor 1 and $28.78 \%$ in factor 2 ) of the variability contained in the set of original variables. The variables Tmax, Insolation, Thermal Amplitude, SWMFC, $\mathrm{RH}$ and Rainfall characterized factor 1 (Figure 7). The climatic variables Tmax, Insolation, Thermal Amplitude act contrary to the fructification phase SWMFC. That is, when the value of any variable of these observations increases the value of the other variable of the other quadrant that is in the opposite direction decreases (Figure 7). However, for rainfall and relative humidity the SWMFC phase acts directly, indicating that when the value of these climatic variables increases, the value of the fruiting phase also increases.

Observing the variation of the factorial loads in Figure 8, factor 1, with greater discriminatory power, which accounts for $50.31 \%$ of the variability, presents between January and April its highest values of positive factor loads, months of higher rainfall and relative humidity in the region. Conversely, between the months of September and November, less rainy months, the highest negative loads are observed (Figure 8), characterizing the sensitivity mainly of the fruiting season of the plant, as well as the variations of weather and climate in the region.

The biplot analysis showed that the phenological phases located in the same quadrant as the agrometeorological variables are positively associated, demonstrating that

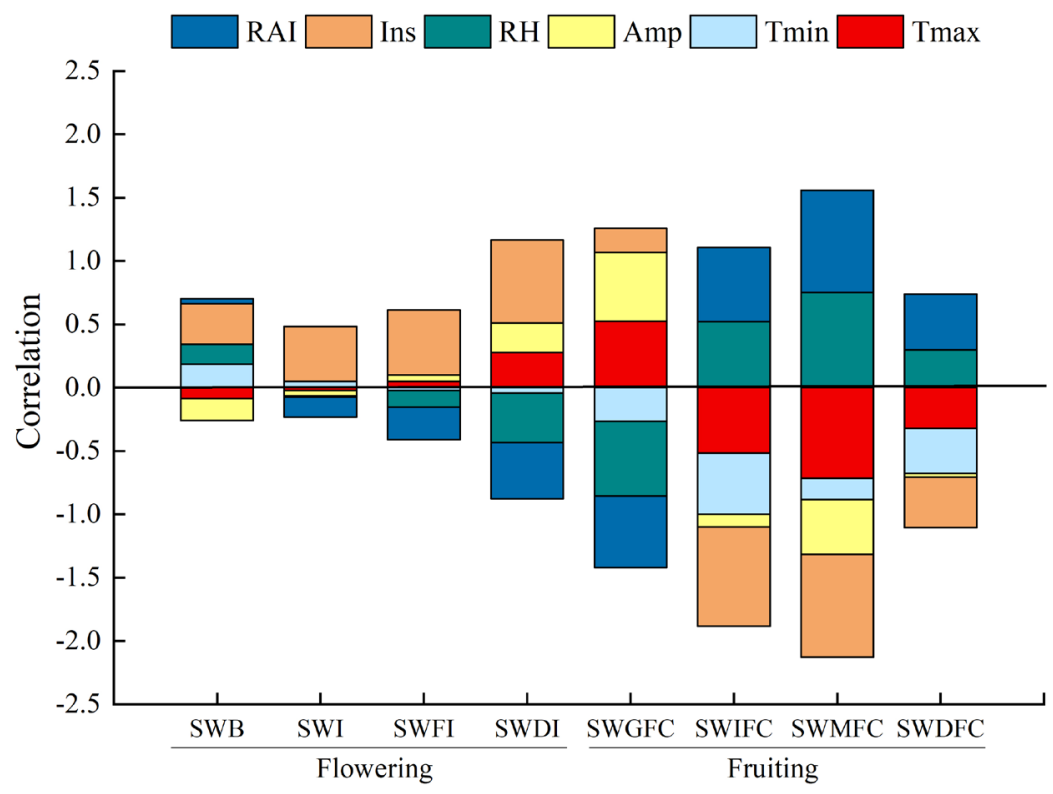

Figure 6: Correlation between agrometeorological variables and phenological phases of flowering and fruiting at the BAG - Tucumã, in Belém-PA. (Climate variables, RAI (Rainfall); Ins (Insolation); RH (Relative humidity); Amp (Thermal Amplitude); Tmin (Temperature minimum); Tmax (Temperature maximum). Phenological phases, SWB (\% of stems with bracts); SWI (\% of stems with inflorescences); SWFI (\% of stems with fertilized inflorescences); SWDI (\% of stems with dried inflorescences); SWGFC (\% of stems with green fruit clusters); SWIFC (\%of stems with immature fruit clusters); SWMFC (\%of stems with mature fruit clusters); SWDFC (\%of stems with dry fruit clusters). 
Table 1: Identification of the factor load of the agrometeorological variables with the phenological variables of tucumã (A. vulgare Mart.) in Belém, PA. Climate variables, RAI (Rainfall); Ins (Insolation); RH (Relative humidity); Amp (Thermal Amplitude); Tmax (Temperature maximum).

\begin{tabular}{ccc}
\hline VARIABLE & Factor 1 & Factor 2 \\
\hline Tmax & -0.95 & - \\
Ins & -0.84 & - \\
Amp & -0.77 & - \\
SWMFC & 0.83 & - \\
RH & 0.97 & - \\
RAI & 0.96 & - \\
SWB & - & -0.91 \\
SWI & - & -0.91 \\
SWFI & - & -0.74 \\
Variance explained & 4.98 & 2.58 \\
Percentage of variance & 55.31 & 28.78 \\
explained (\%) & & \\
\hline
\end{tabular}

SWIFC- \% of stems with immature fruit clusters; SWMFC - \% of stems with mature fruit clusters; SWB - \% of stems with bracts; SWI - \% of stems with inflorescences; SWFI- \% of stems with fertilized inflorescences; SWGFC - \% of stems with green fruit clusters.
(SWB), (SWI) and (SWFI) possess a strong association with insolation, while (SWGFC) has a strong association with maximum temperature (Tmax) and thermal amplitude (Amp).

With respect to the NDVI analysis, in July 2016 there was more green area in the BAG-Tucumã showing that the stems were maintaining their leaves and their photosynthetic capacity because the NDVI values were above 0.41 (Figure 9). In the northern part of the study area there are very low NDVI values (-1 and 0.29$)$, with areas with little or no vegetation, indicating anthropogenic pressure and reinforcing the role of the densely vegetated area as being crucial to climate regulation in the region.

Compared to the EVI data between the years 2000 to 2017, Figure 9 shows that the values from 2014 to 2015 are higher, and this indicates a response from the soil. In 2016 the EVI data are less than 0.5, a result that confirms that from the NDVI data in which the vegetation index was between 0.4 and 1.0, and this result is a reflection of annual variation in the years analyzed due to the spectrum of reflection of the vegetation recorded by the remote sensors. Seasonal variations in climatic conditions can increase or limit vegetation growth and development, thus altering the rate of biomass accumulation and, consequently, rate of senescence under conditions of stress (Nuche and Alados, 2018) and the EVI data captured the annual dynamic of the vegetation with respect to the effects of climate (Almeida et al., 2008).

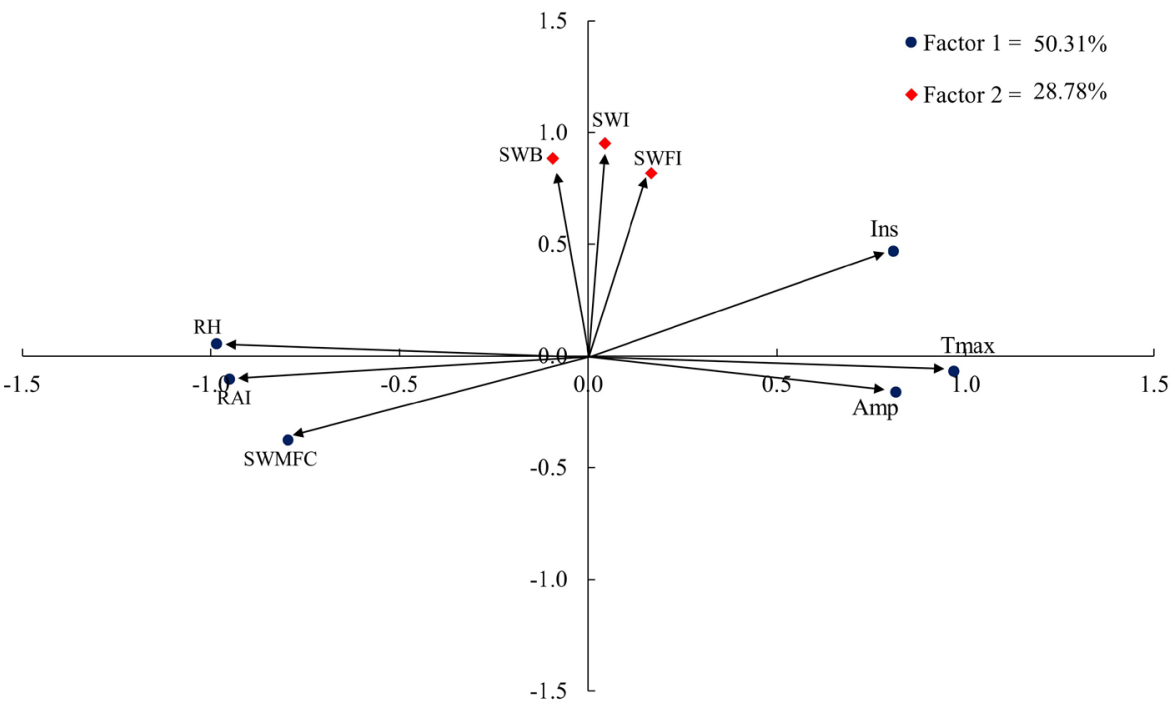

Figure 7: Biplot between agrometeorological variables and phenological phases of flowering and fruiting in tucumã (A. vulgare Mart.) at BAG-Tucumã, Embrapa Eastern Amazon, Belém, PA. Climate variables, RAI (Rainfall); Ins (Insolation); RH (Relative humidity); Amp (Thermal Amplitude); Tmax (Temperature maximum). Phenological phases, SWB (\% of stems with bracts); SWI (\% of stems with inflorescences); SWFI (\% of stems with fertilized inflorescences); SWMFC (\%of stems with mature fruit clusters). 


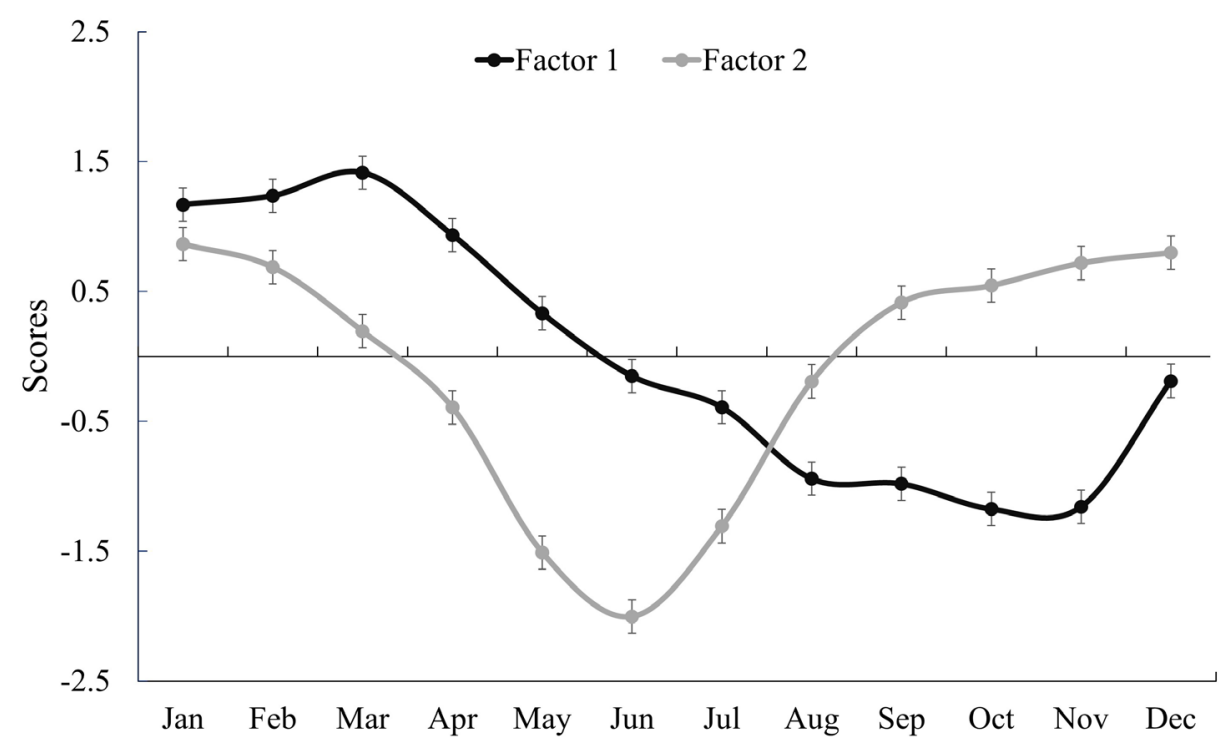

Figure 8: Factor loads analyzed in two processes during one year comparing agrometeorological data with phenological phases of flowering and fruiting.
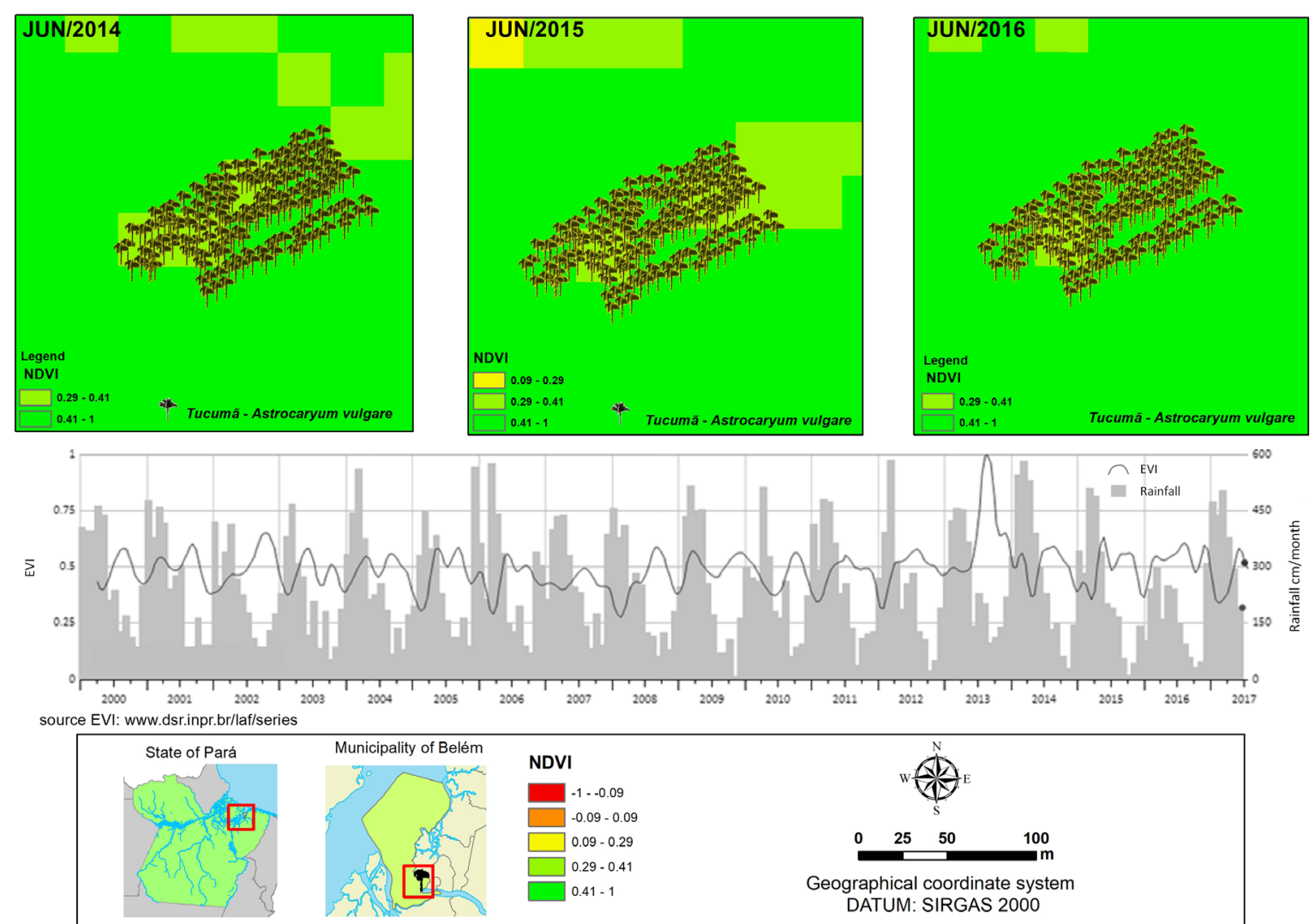

Figure 9: Normalized Difference Vegetation Index (NDVI) values at BAG - Tucumã at Embrapa Eastern Amazon in Belém, Pará. 


\section{CONCLUSIONS}

Agrometeorological variables such as rainfall, thermal amplitude, and insolation showed positive correlations with the flowering and fruiting phenological phases in tucumã; The percent of stems with bracts responded positively to the volume of rainfall and to the number of hours of insolation, followed by thermal amplitude; The percent of stems with emission of inflorescences and with fertilized inflorescences was highly correlated with insolation, indicating that when there is a greater number of hours of insolation in Belém there will be greater fertilization of inflorescences, possibly due to visits by pollinating insects; Rainfall and air relative humidity influence the percent of individuals with immature and also with mature fruit clusters. High maximum temperatures compromise the expression of the percent of stems with green fruit clusters in this species.

\section{ACKNOWLEDGEMENTS}

The authors express their gratitude to the Research Foundation of the State of Pará (FAPESPA) for the funding for this project which was of fundamental importance for the development of this research.

\section{REFERENCES}

AGARWALA, M. et al. Assessing the relationship between human well-being and ecosystem services: A review of frameworks. Conservation and Society, (12):437-449, 2014.

ALMEIDA, A. Q. et al. Enhanced vegetation index (EVI) na análise da dinâmica da vegetação da Reserva Biológica de Sooretama, ES. Revista Árvore, 32(6):1099-1107, 2008.

BIONDI, D.; LEAL, L.; BATISTA, A. Fenologia do florescimento e frutificação de espécies nativas dos Campos. Acta Scientiarum. Biological Sciences, 29(3):269-276, 2007.

BRAZ, A. M.; ÁGUAS, T. A.; GARCIA, P. H. M. Análise de índices de vegetação NDVI e SAVI e Índice de Área Folear (IAF) para a comparação da cobertura vegetal na bacia hidrográfica do córrego Ribeirãozinho, município de Selvíria - MS. Revista Percurso - Nemo, 7(2):05-22, 2015.

CONGA, N. et al. Spring vegetation green-up date in China inferred from SPOT NDVI data: A multiple model analysis. Agricultural and Forest Meteorology, 165:104-113, 2012.

GARSON, G. D. Testing of assumptions, from statnotes: Topics in multivariate analysis. 2011. Available in: < http:// chass.ncsu.edu/garson/pa765.statnote.html> Access in: Nov, 07, 2017.

GILMAN, S. E. et al. A framework for community interactions under climate change. Trends in Ecology \& Evolution, (25):325-331, 2010.

HAIR, J. R. et al. Análise Multivariada de Dados 6.ed. Porto Alegre: Bookman, 2009. 688p.

INMET - INSTITUTO NACIONAL DE METEOROLOGIA, 2017: BDMEP - Banco de Dados Meteorológicos para Ensino e Pesquisa. Available in: <http://www.inmet.gov.br/portal/ index.php?r=bdmep/bdmep>. Access in: Oct, 09, 2017.

LAPOLA, D. M.; OYAMA, M. D.; NOBRE, C. A. Exploring the range of climate biome projections for tropical South America: The role of $\mathrm{CO}_{2}$ fertilization and seasonality. Global Biogeochemical Cycles, 23:1-16, 2009.

LAPOLA, D. M. et al. A new world natural vegetation map for global changes studies. Anais da Academia Brasileira de Ciências, 80(2), 397-408, 2008.

MALHADO, A. C. M. et al. The ecological biogeography of Amazonia. Frontiers of Biogeography, 5(2):103-112. 2013.

MARTORANO, L. G. et al. Climate conditions in the eastern amazon: Rainfall variability in Belem and indicative of soil water defict. African Journal of Agricultural Resarch, 12(21):1801-1810, 2017.

MORISETTE, J. T. et al. Liang Tracking the rhythm of the seasons in the face of global change: phenological research in the 21 st century. Frontiers in Ecology and the Environment, 7(5):253-260, 2009.

NONATO, E. A. et al. Tratamento estatístico dos parâmetros da qualidade das águas da bacia do Alto Curso do Rio das Velhas. Química Nova, 30(4):797-804, 2007.

NUCHE, P.; ALADOS, C. L. Shrub interactions drive vegetation succession of subalpine grasslands under two climatic conditions. Journal of Plant Ecology, 11(2):297-307, 2018.

OLIVEIRA, M. S. P. et al. Tucumã-do-Pará. In: LOPES, R. et al. (ed.) - Brasília, DF : Embrapa, cap. 13, p.395-432. 2015.

PONZONI, F. J.; SHIMABUKURO, Y. E. Sensoriamento Remoto no Estudo da Vegetação. 1. ed. São José dos Campos: Editora Parêntese, 2007.

POORTER, L. et al. Diversity enhances carbon storage in tropical forests. Global Ecology Biogeography, 24(11):1314-1328, 2015. 
ROUSE, J. W. et al. Monitoring vegetation systems in the Great Plains with ERTS. In 3rd ERTS Symposium, NASA SP-351 I, p.309-317. 1973.

SHARMA, S. Applied Multivariate Techniques. Ed. John Wiley and Sons. EUA, 1996. 493p.
SIMEONOV, V. et al. Environmental modeling and interpretation of river water monitoring data. Analytical and Bioanalytical Chemistry, 374:898-905, 2002.

STEEGE, H. et al. Hyperdominance in the Amazonian tree flora. Science, 342(6156):1243092, 2013. 